\title{
Lysis of Mycoplasma, Bacterial Protoplasts, Spheroplasts and L-forms by Various Agents
}

\author{
By S. RAZIN AND M. ARGAMAN \\ Department of Clinical Microbiology, Hebrew University-Hadassah \\ Medical School, Jerusalem, Israel
}

(Received 31 May 1962)

\begin{abstract}
SUMMARY
The susceptibility to lysis of several Mycoplasma organisms, bacterial protoplasts, spheroplasts, L-forms and intact bacteria was compared. The Mycoplasma and L-forms were much more resistant to lysis by osmotic shock and to alternate freezing and thawing than were the bacterial protoplasts and spheroplasts. Like bacterial protoplasts, the mycoplasmas were very sensitive to lysis by surface-active substances, primary alcohols and alkali; bacterial spheroplasts and $\mathbf{L}$-forms were less sensitive to lysis by these agents. All the organisms tested, except intact bacteria, showed various degrees of sensitivity to lysis by pancreatic lipase. The mycoplasmas and the L-forms were completely resistant to the lytic action of lysozyme. The mycoplasmas differed from all other microorganisms tested in being sensitive to lysis by digitonin and saponin. This sensitivity to digitonin was considerably smaller when the organism was grown in a cholesterol-free defined medium. The structure and properties of the Mycoplasma cell envelope are discussed on the basis of the present findings.
\end{abstract}

\section{INTRODUCTION}

One of the most peculiar features of the Mycoplasma organisms (pleuropneumonialike organisms, PPLO) is their thin and plastic envelope. Evidence for the absence of a rigid cell wall has been furnished by electron microscope studies of whole mycoplasma cells and of ultrathin sections (Van Iterson \& Ruys, 1960; Ruys \& Van Iterson, 1961; Edwards \& Fogh, 1960; Sharp 1960; Klieneberger-Nobel, 1962). Ultrathin sections of mycoplasma organisms showed the envelope to consist of two electron-dense outer layers and a transparent inner zone (Van Iterson \& Ruys, 1960; Ruys \& Van Iterson, 1961) resembling the 'unit membrane' which is of universal distribution in nature (Robertson, 1959). The thickness of the mycoplasma cell envelope was found to be $\approx 75 \AA$ by Van Iterson \& Ruys (1960), similar to that of the bacterial plasma membrane (Thorsson \& Weibull, 1958; van Iterson, 1961 ; Imaeda \& Convit, 1962). Lack of the 'mucopeptide' polymer in Mycoplasma (Kandler \& Zehender, 1957; Plackett, 1959; Razin \& Argaman, 1961) further supported the assumption that Mycoplasma has no cell wall and is limited by a membrane which resembles the plasma membrane of bacterial protoplasts. Very little is known as yet about the chemical composition of the Mycoplasma envelope. The presence of a cardiolipin-like compound in the envelope of Mycoplasma mycoides var. mycoides was suggested by Rodwell \& Abbot (1961). Complex phosphatidic 
acid, resembling cardiolipin, was found to be the major lipid component of the bacterial plasma membrane (Weibull \& Bergström, 1958; Gilby, Few \& McQuillen, 1958). Carotenoid pigments were found in the 'membrane fraction' of Mycoplasma laidlawii (Rothblat \& Smith, 1961), as in the plasma membrane of Micrococcus lysodeikticus (Gilby et al. 1958). Rothblat \& Smith (1961) found cholesterol or derivatives of it in the 'membrane fraction' of several Mycoplasma strains. No cholesterol has so far been found in any of the bacterial plasma membranes studied (Weibull \& Bergström, 1958; Gilby et al. 1958).

The apparent similarity between the Mycoplasma envelope and that of bacterial protoplasts prompted us to compare the susceptibility of these organisms to lysis by various physical and chemical agents. Bacterial spheroplasts and stable L-forms containing defective cell walls (Klieneberger-Nobel, 1960) were also examined.

\section{METHODS}

Organisms. Mycoplasma laidlawii strain A (PG 8) was obtained from Dr D. G. ff. Edward (The Wellcome Research Laboratories, Beckenham, Kent). Mycoplasma mycoides var. capri and the stable L-form of Streptobacillus moniliformis were kindly provided by Dr E. Klieneberger-Nobel (The Lister Institute of Preventive Medicine, London). Mycoplasma hominis no. 23 was isolated in our laboratory from a case of vaginitis. Micrococcus lysodeikticus and Escherichia coli strain B were obtained from the collection of the Department.

Media and organism suspensions. Mycoplasma laidlawii and M. mycoides var. capri were grown in a modified liquid Edward medium (Razin \& Oliver, 1961) containing $2 \%(\mathrm{v} / \mathrm{v})$ Bacto PPLO serum fraction. Mycoplasma hominis and the L-form of Streptobacillus moniliformis were grown in the same medium, but with $15 \%(\mathrm{v} / \mathrm{v})$ inactivated (pooled) human serum instead of PPLO serum fraction. Growth was carried out in rotated Erlenmeyer flasks for 24-48 hr. at $37^{\circ}$. The organisms were collected in a Sharples supercentrifuge and resuspended in de-ionized water or in $\mathrm{M}$-sucrose $+0.05 \mathrm{M}-\mathrm{NaCl}$ solution, referred to below as the sucrose medium. Micrococcus lysodeikticus was grown on brain-heart infusion agar (Difco) for $18 \mathrm{hr}$. at $37^{\circ}$, collected, washed three times in de-ionized water and resuspended in de-ionized water or in the sucrose medium.

Preparation of protoplasts. Protoplasts of Micrococcus lysodeikticus were prepared by the action on the washed organisms (at equiv. $10 \mathrm{mg}$. dry wt./ml.) of crystalline lysozyme (100 $\mu \mathrm{g} . / \mathrm{ml}$.) in the sucrose medium (Gilby \& Few, 1960a). The quantitative conversion of the bacteria into protoplasts was usually accomplished after incubation at $37^{\circ}$ for $30-45 \mathrm{~min}$. The resulting protoplasts were centrifuged down and after the supernatant fluid was decanted, were gently resuspended in the sucrose medium.

Preparation of spheroplasts. The method described by Lederberg (1956) was used. Escherichia coli B was grown in 1 1. nutrient broth (Difco) at $37^{\circ}$ for $18 \mathrm{hr}$. The broth culture was then transferred to $3 \mathrm{l}$. fresh nutrient broth containing $20 \%(\mathrm{w} / \mathrm{v})$ sucrose $+0 \cdot 2 \%(\mathrm{w} / \mathrm{v}) \mathrm{MgSO}_{4} \cdot 7 \mathrm{H}_{2} \mathrm{O}+1000$ units crystalline penicillin $\mathrm{G} / \mathrm{ml}$. Incubation was continued at $37^{\circ}$, and the formation of spheroplasts followed by phase-contrast microscopy. The quantitative conversion of the bacilli into spheroplasts usually took place after 4-5 hr. of incubation. The spheroplasts were sedimented by 
centrifugation at $7000 \mathrm{~g}$ for $15 \mathrm{~min}$. and resuspended in $20 \%(\mathrm{w} / \mathrm{v})$ sucrose $+\mathbf{0 . 2} \%$ (w/v) $\mathrm{MgSO}_{4} \cdot 7 \mathrm{H}_{2} \mathrm{O}$ solution.

Chemicals. Spermine tetrahydrochloride was the product of Hoffmann La Roche and Co. Ltd. (Basle, Switzerland); protamine sulphate was obtained from L. Light \& Co. Ltd. (Colnbrook, Bucks., England) poly-L-lysine (n-34) was a gift of Professor E. Katchalski (The Weizmann Institute of Science, Rehovoth, Israel). Sodium lauryl sulphate(U.S.P.) was the product of Amend Drug and Chemical Co. (New York 10, N.Y., U.S.A.). Cetyltrimethylammonium bromide (pure: CTAB) was obtained from Hopkin \& Williams Ltd. (London, E.C. 1). Sodium deoxycholate and sodium taurocholate were the products of Difco Laboratories, Inc., Detroit 1, Michigan, U.S.A. 'Tween' 80, U.S.P. was bought from the City Chemical Co. (New York) and 'Triton' WR-1339 from Winthrop-Stearns Inc. (New York 18, N.Y., U.S.A.). Ethanol, $n$-propanol and $n$-butanol of A.R. quality were used without further purification. Digitonin was obtained from the Nutritional Biochemicals Corp. (Cleveland, Ohio, U.S.A.) and saponin from Hopkin \& Williams Ltd. (London, E.C. 1). Lysozyme chloride (crystalline, egg white) was the product of L. Light \& Co. Trypsin $(2 \times$ crystallized), lipase (bovine), bromelin and pepsin $(1 / 20,000)$ were bought from Nutritional Biochemicals Corporation.

\section{Examination of lysis}

Tonicity changes. Test tubes contained $4 \mathrm{ml}$. of serial twofold dilutions of sucrose medium or of a $2 \mathrm{M}-\mathrm{NaCl}$ (in $0.01 \mathrm{~m}$-phosphate buffer, $\mathrm{pH} \mathrm{6.8)} \mathrm{solution.} \mathrm{Each} \mathrm{test}$ tube received $0.1 \mathrm{ml}$. suspension of test organism to an optical density (OD) of $0 \cdot 3-0 \cdot 4$ at $500 \mathrm{~m} \mu$. Changes in optical density were measured after $30 \mathrm{~min}$. incubation at room temperature in a 'Unicam SP 500' spectrophotometer. The effect of the substitution of other solutes for the sucrose or $\mathrm{NaCl}$ in the suspending medium was tested by the method of Mitchell \& Moyle $(1956 a)$. Samples $(0 \cdot 1 \mathrm{ml}$.) of suspensions of the organisms in the sucrose medium were added to $4 \mathrm{ml}$. of $1.5 \mathrm{M}$ solution (in $0.01 \mathrm{M}$-phosphate buffer, $\mathrm{pH} \mathrm{6.8)}$ of the solute to be tested. The rate of lysis was measured by optical density changes at room temperature during short time intervals.

Alternate freezing and thawing. Suspensions of the organisms were made in dilutions of the sucrose medium or in de-ionized water. The suspensions were dispensed into test tubes in quantities of $4 \mathrm{ml}$. and frozen in an ethanol bath at $-24^{\circ}$. When frozen, the test tubes were transferred for thawing to a water bath at $40^{\circ}$. This procedure was repeated as many times as required and the optical density measured after each freezing and thawing.

Heating. Suspensions of organisms were made in sucrose medium, dispensed in $4 \mathrm{ml}$. quantities in test tubes and heated for $10 \mathrm{~min}$. at $40^{\circ}, 50^{\circ}, 60^{\circ}, 70^{\circ}$ or $80^{\circ}$. The optical density of the suspensions was measured as described above.

Chemicals. Solutions of the chemicals to be tested were prepared in $4 \mathrm{ml}$. quantities of sucrose medium or in de-ionized water. Each test tube received $0 \cdot 1 \mathrm{ml}$. of suspension of organism in sucrose medium or de-ionized water. Changes in the optical densities of the suspensions were determined after $30 \mathrm{~min}$. of incubation at room temperature. In some experiments where ionic detergents were tested, the organisms were pre-treated with uranyl nitrate according to Gilby \& Few 
$(1960 a)$. The organisms were suspended in the usual sucrose medium, containing different concentrations of uranyl nitrate. After $30 \mathrm{~min}$. incubation at room temperature the organisms were centrifuged down, resuspended in sucrose medium and recentrifuged. Finally, they were resuspended, in sucrose medium and lysis with the detergents was tested as above.

Enzymes. The sensitivity of the organisms to the lytic action of lysozyme was tested on washed organisms suspended in 0.067 M-phosphate buffer (pH 6.8; Smolelis \& Hartsell, 1949) or on organisms pre-treated by heating and changing pH from 3.5 to 10.5 (Grula \& Hartsell, 1957), or treatment by freezing and thawing (Kohn, 1960), trypsinization (Becker \& Hartsell, 1954), treatment with ethylenediaminetetra-acetate (EDTA; Repaske, 1956).

The effect of proteolytic and lipolytic enzymes was tested on organisms suspended in 0.067 $\mathrm{M}$-phosphate buffer ( $\mathrm{pH} \mathrm{7.0)}$ ), or $0.01 \mathrm{M}$-phosphate buffer ( $\mathrm{pH} \mathrm{8.0)}$ containing $0.002 \mathrm{M}-\mathrm{Mg}^{++}, \mathrm{Ca}^{++}$and $\mathrm{Mn}^{++}$as chloride. For comparative experiments with bacterial protoplasts and spheroplasts, sucrose was added to the buffer to final concentration of $1 \mathrm{M}$. The test tubes thus contained $3.5 \mathrm{ml}$. enzyme solution in buffer and $0.5 \mathrm{ml}$. suspension of organisms. Parallel experiments were carried out with organisms pre-treated by heating at $70^{\circ}$ for $15 \mathrm{~min}$. The test tubes were incubated at $37^{\circ}$ and optical density changes determined at various time intervals.

Agglutination by polyamines. Agglutination of the organisms by polyamines was tested in de-ionized water according to the method of Razin \& Rozansky (1959).

\section{RESULTS}

\section{Lysis by decreasing the tonicity of the medium}

The effect on the test organisms of decreasing the tonicity of the medium was measured by observing the optical density changes of suspensions prepared in sucrose or $\mathrm{NaCl}$ solutions (Fig. 1). The protoplasts of Micrococcus lysodeikticus were very sensitive to decreases in tonicity and underwent almost complete lysis at $\mathbf{0 . 2 5} \mathrm{M}$-sucrose. The spheroplasts of Escherichia coli were less sensitive to lysis than the protoplasts; decreases in the optical density of their suspensions appeared only at concentrations of sucrose less than 0.12M. The Mycoplasma organisms observed and the L-form of Streptobacillus moniliformis were not lysed to any significant degree even by transfer from M-sucrose solution to de-ionized water. The increase in the optical density of the Mycoplasma suspensions at higher sucrose concentrations might have been due to the shrinkage of the plastic cells in the hypertonic medium, while the decrease in optical density at the highest sucrose concentrations was apparently caused by depression of the light scattering of the organisms because of the high refractive index of the concentrated sucrose solution (Gilby \& Few, 1959). The decrease of the optical density of bacterial suspensions at increasing sucrose concentrations is clearly demonstrated in the case of intact Micrococcus lysodeikticus (Fig. 1). The results were similar to those described above with media which contained different amounts of sodium chloride. Attempts at assessment by phase contrast microscopy (maximal magnification $\times 1250$ ) of changes in cell volume of Mycoplasma laidlawii suspended in media of various tonicity failed owing to the very small dimensions of the Mycoplasma organisms.

The nature of the solute used for obtaining the required tonicity of the suspending 
medium was of great importance. Solutes capable of penetrating bacterial protoplasts (e.g. glycerol, D-ribose) were unsuitable for use as osmotic stabilizers (Mitchell \& Moyle, 1956a). Replacement of the sucrose in our medium by other sugars or by glycerol was therefore tried. It may be seen from Fig. 2 that the protoplasts of Micrococcus lysodeikticus and the spheroplasts of Escherichia coli underwent complete and immediate lysis when suspended in $1.5 \mathrm{M}$-glycerol solution. Lysis in 1.5 MD-ribose solution was slower. Mycoplasma laidlawii and the L-form of Streptobacillus

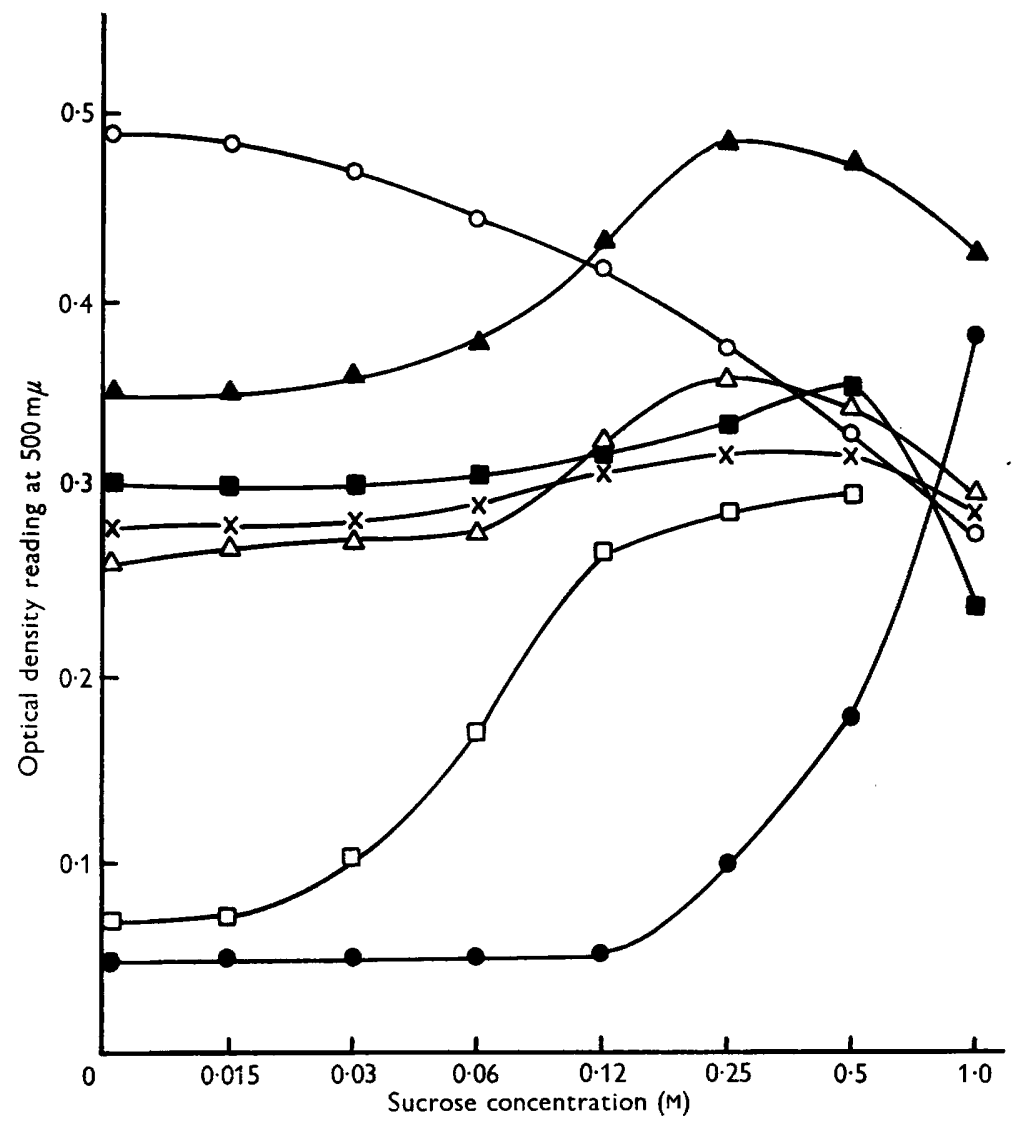

Fig. 1. The effect of the sucrose concentration in the suspension medium on the optical density of suspensions of Mycoplasma laidlawii $(\triangle)$; Mycoplasma mycoides var. capri (A); Mycoplasma hominis (E); L-form of Streptobacillus moniliformis ( $\times$ ); spheroplasts of Escherichia coli ( $\square$ ); Micrococcus lysodeikticus (O) and protoplasts of $\boldsymbol{M}$. lysodeikticus ( $\bullet$ ). Optical density measured after $30 \mathrm{~min}$. incubation at room temperature.

moniliformis were lysed to a certain degree in glycerol or D-ribose solution. No significant lysis of any of the organisms tested occurred when $1.5 \mathrm{M}$-glucose or fructose replaced sucrose in the suspending medium. Magnesium sulphate $(0 \cdot 2 \%$, w/v) decreased the degree of lysis of the spheroplasts of $E$. coli in $1.5 \mathrm{M}$-glycerol or in de-ionized water by about one half. Spermine $(10 \mu \mathrm{g} . / \mathrm{ml}$. $)$ completely protected the spheroplasts from lysis in these media. 


\section{Lysis by alternate freezing and thawing}

When suspended in the sucrose medium, Mycoplasma organisms, L-form of Streptobacillus moniliformis, spheroplasts of Escherichia coli and intact Micrococcus lysodeikticus were not lysed by alternate freezing and thawing. Ten transfers from

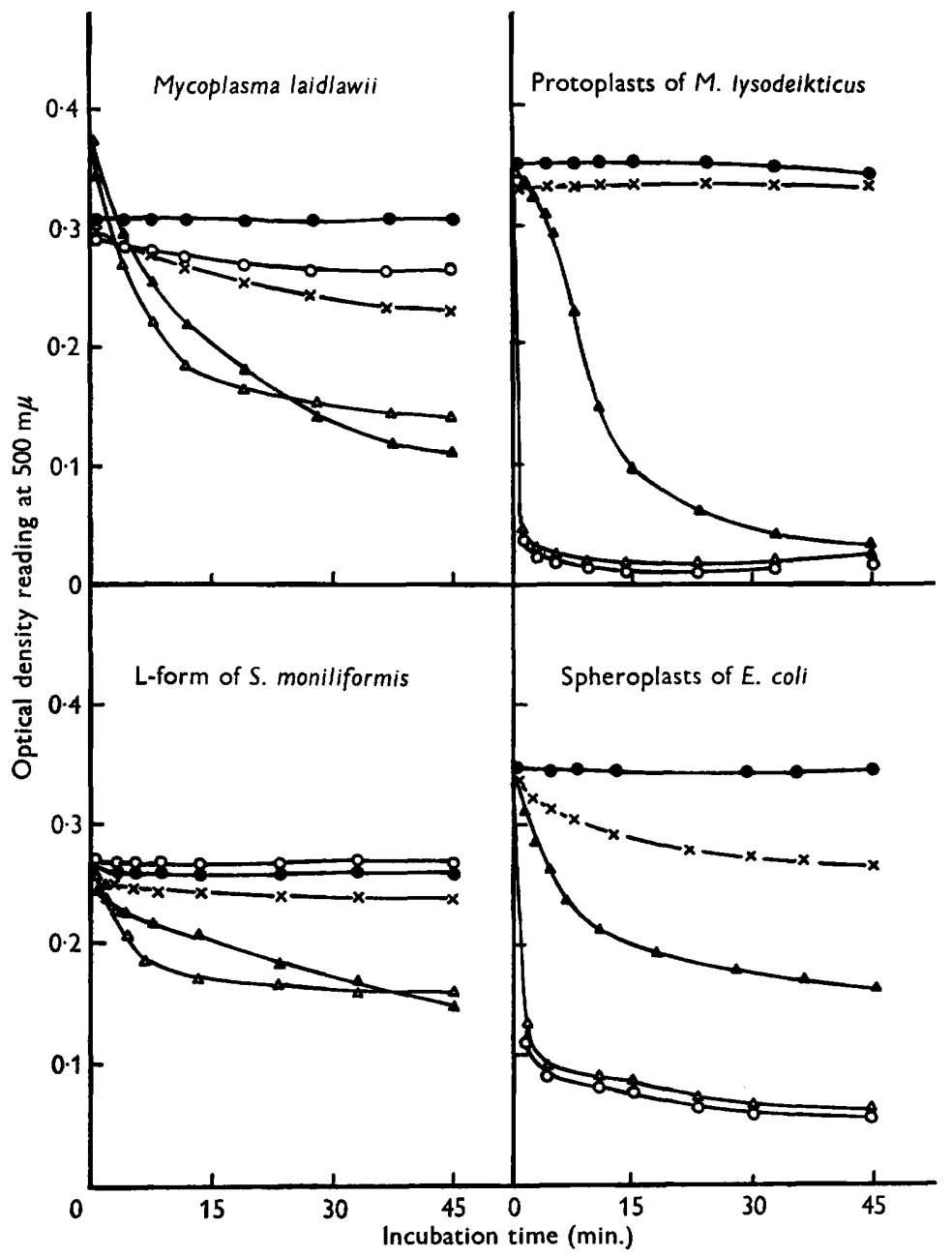

Fig. 2. Optical density changes of suspensions prepared in $1.5 \mathrm{~m}$ solutions (in $0.01 \mathrm{M}$ phosphate buffer, $\mathrm{pH} 6.8)$ of sucrose $(O)$; glucose $(x)$; glycerol $(\triangle)$; ribose $(\Delta)$; $0.01 \mathrm{M}$ phosphate buffer (pH 6.8) alone (O). Incubation was carried out at room temperature.

$-24^{\circ}$ to $+40^{\circ}$ did not cause any significant decrease in the optical density of suspensions of these organisms, while protoplasts of $\boldsymbol{M}$. lysodeikticus underwent almost complete lysis after several alternate freezings and thawings (Fig. 3). However, the Mycoplasma organisms became sensitive to lysis when the sucrose concentration in the medium was markedly decreased. The degree of lysis in the presence of $0.006 \mathrm{M}$-sucrose equalled that in de-ionized water, but even $0.06 \mathrm{M}$ sucrose had a significant protective effect (Fig. 3). 
Spermine, known to protect some fragile organisms and organelles from lysis under unfavourable conditions (Tabor, Tabor \& Rosenthal, 1961) was tested for such effect on Mycoplasma treated by freezing and thawing in de-ionized water. A concentration of $10 \mu \mathrm{g} . / \mathrm{ml}$. of this polyamine protected Mycoplasma organisms from lysis by ten alternate freezings and thawings, while $2 \mu \mathrm{g} . / \mathrm{ml}$. was insufficient. These results were obtained with both Mycoplasma mycoides var. capri and $M$. laidlawii. Spermine, protamine and poly-L-lysine agglutinated M. mycoides var.

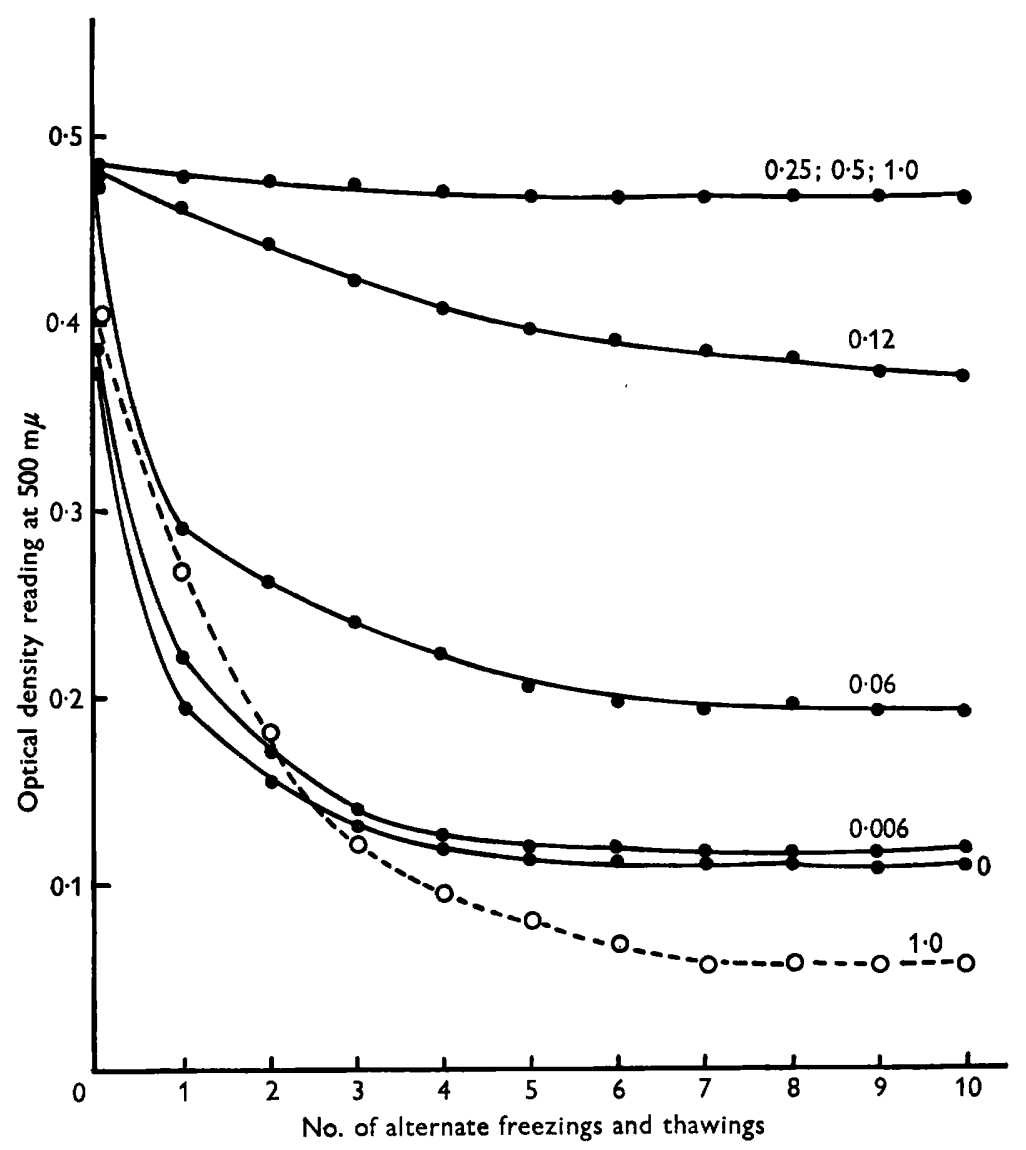

Fig. 3. Lysis of Mycoplasma laidlazwi by alternate freezing and thawing in media containing different molar concentrations of sucrose (indicated in figure). The lysis curve of protoplasts of Micrococcus lysodeikticus in M-sucrose (O--O) is included for comparison.

capri and $M$. laidlawii within a certain range of concentrations (spermine, 80$1250 \mu \mathrm{g} . / \mathrm{ml}$.; protamine, $80-5000 \mu \mathrm{g} . / \mathrm{ml}$; polylysine, 80-320 $\mu \mathrm{g} . / \mathrm{ml}$.). Intact $M$. lysodeikticus organisms were agglutinated by the same polyamine concentrations. The aggregates were formed within 1-2 hr. of incubation at $37^{\circ}$; they sedimented overnight, leaving the supernatant fluid clear. 


\section{Lysis by heating}

Spheroplasts of Aerobacter aerogenes were found to lyse at temperatures of about 56-65 ${ }^{\circ}$ (Gebicki \& James, 1960). Similar experiments with our test organisms suspended in the sucrose medium showed that the optical density of the suspension of Micrococcus lysodeikticus protoplasts decreased by about $50 \%$ after heating at $80^{\circ}$ for $10 \mathrm{~min}$. A decrease of about $\mathbf{8 0} \%$ in optical density was found with the Mycoplasma suspensions heated to the same temperature; the optical density of these suspensions began to decrease at $50^{\circ}$.

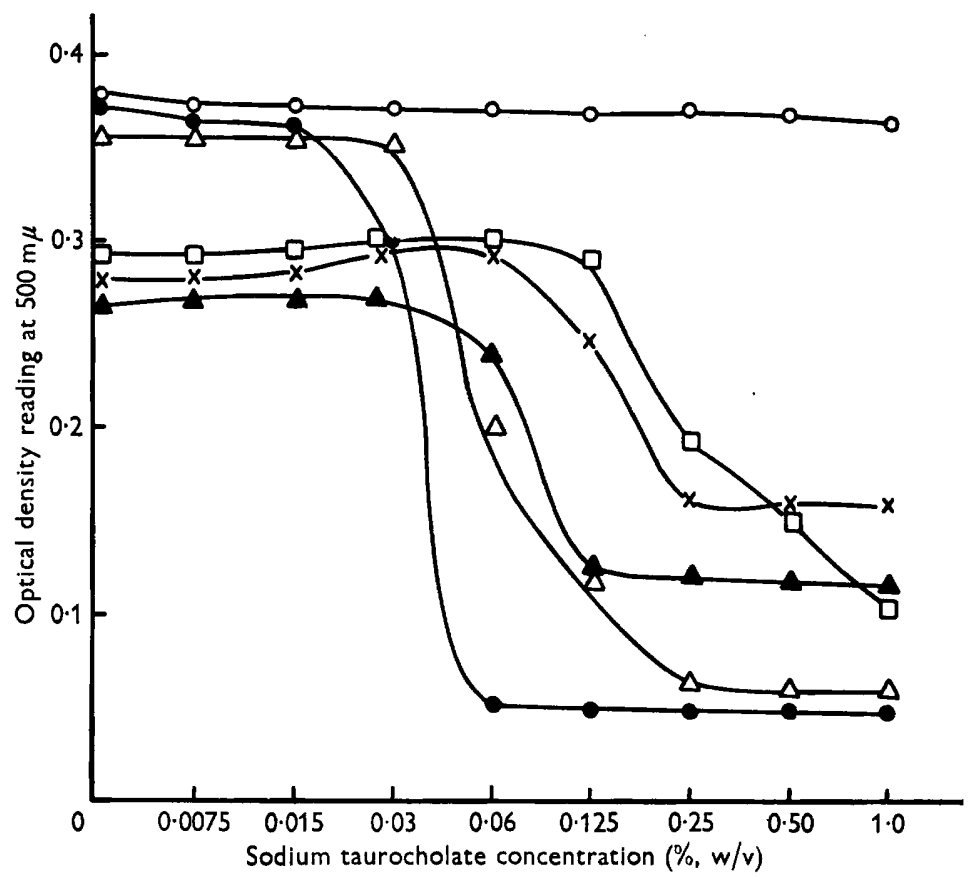

Fig. 4. Lysis by sodium taurocholate. Mycoplasma laidlarevi $(\Delta)$; Mycoplasma mycoides var. capri (A); L-form of Streptobacillus moniliformis $(x)$; spheroplasts of Escherichia coli (口); intact cells of Micrococcus lysodeikticus (O); protoplasts of $M$. lysodeikticus (O). The experiment was carried out in the sucrose medium and optical density was measured after $\mathbf{3 0} \mathbf{~ m i n}$. incubation at room temperature.

\section{Lysis by treatment with surface active agents}

The Mycoplasma organisms tested were sensitive to lysis by sodium deoxycholate and sodium taurocholate (Fig. 4). The Mycoplasma organisms were more sensitive to lysis by these agents than were the L-form of Streptobacillus moniliformis and spheroplasts of Escherichia coli. On the other hand the Mycoplasma organisms were more resistant to lysis than were protoplasts of Micrococcus lysodeikticus. Similar results were obtained with the anionic detergent sodium lauryl sulphate (Fig. 5a). The cationic detergent cetyltrimethylammonium bromide (CTAB) caused lysis of the bacterial protoplasts and of Mycoplasma laidlawii only within a narrow range of concentrations; at higher concentrations agglutination and precipitation of the 


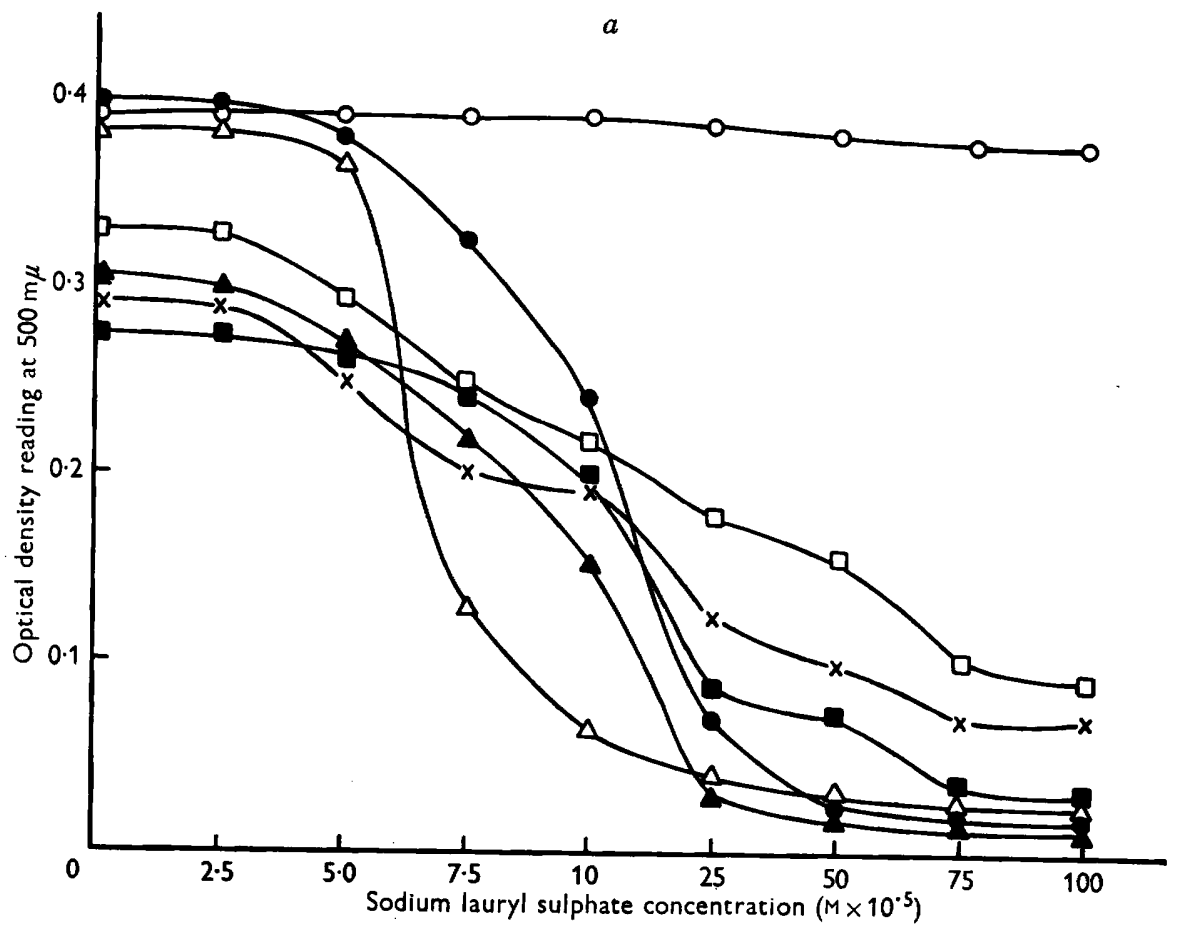

163

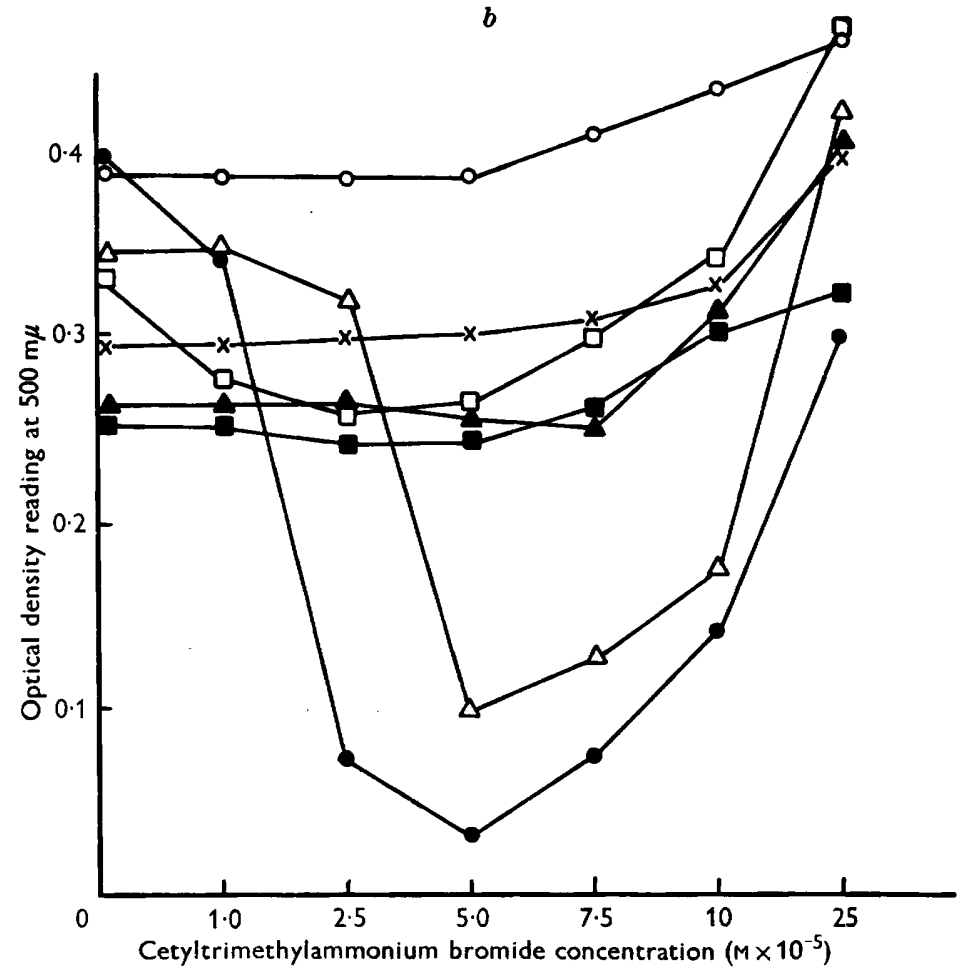

Fig. 5. Lysis by ionic detergents. (a) Sodium lauryl sulphate; (b) cetyltrimethylammonium bromide. Mycoplasma laidlawii $(\triangle)$; Mycoplasma mycoides var. capri ( $\Delta)$; Mycoplasma hominis ( $\mathbf{\square})$; L-form of Streptobacillus moniliformis $(\times)$; spheroplasts of Escherichia coli $(\square)$; intact Micrococcus lysodeikticus (O); protoplasts of $M$. lysodeikticus (๑). The experiment was carried out in the sucrose medium and optical density was measured after incubation for $\mathbf{8 0} \mathrm{min}$. at room temperature. 
organisms occurred and the optical density of their suspensions increased (Fig. $5 b$ ). The cationic detergent CTAB had no marked lytic effect on any of the other organisms tested. Pre-treatment of $\boldsymbol{M}$. laidlawii organisms and $\boldsymbol{M}$. lysodeikticus protoplasts with uranyl nitrate gave protection against lysis by anionic and by cationic detergents (Fig. 6).

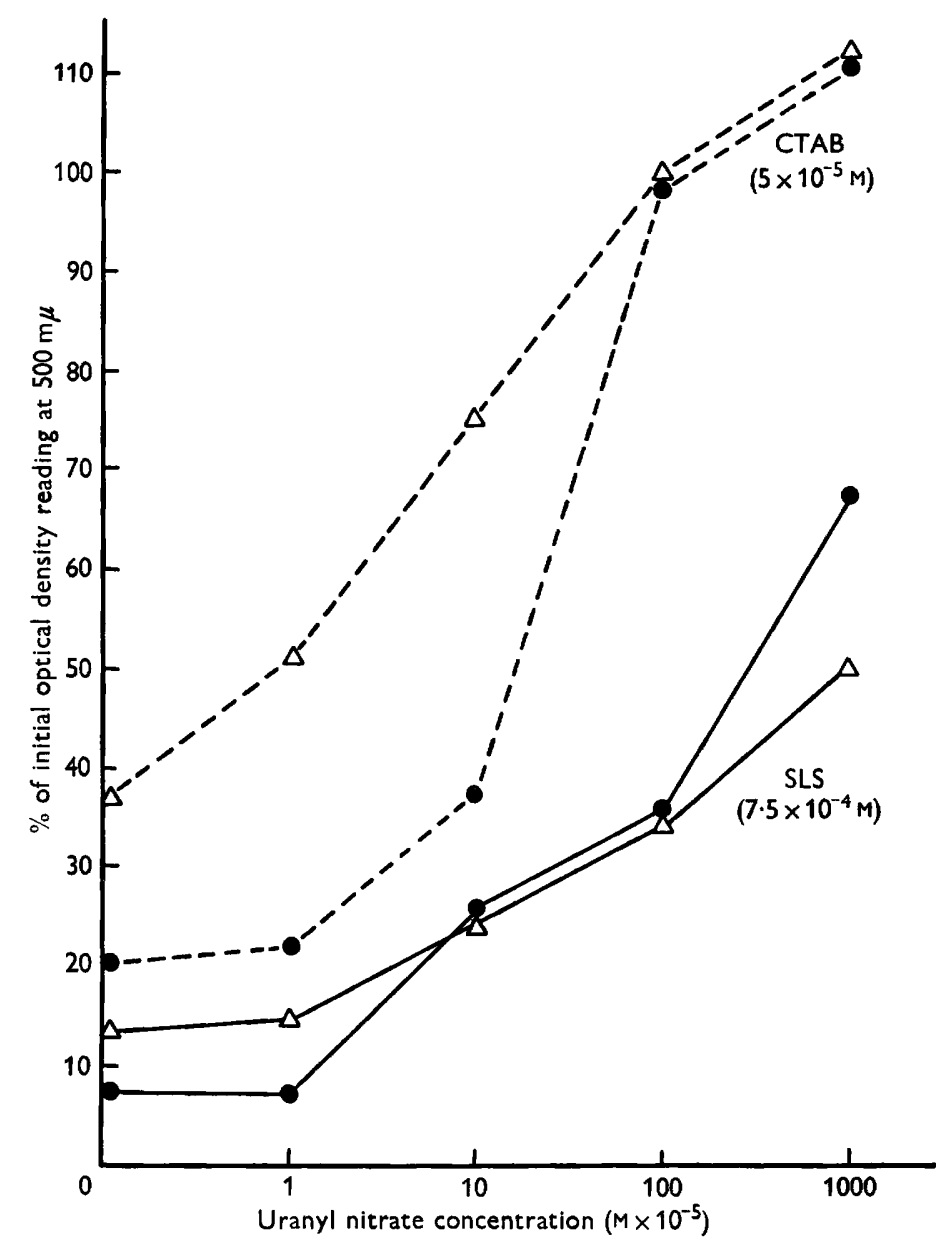

Fig. 6. Lysis by sodium lauryl sulphate (SLS) and cetyltrimethylammonium bromide (CTAB) of Mycoplasma laidlawiii $(\Delta)$ and protoplasts of Micrococcus lysodeikticus ( $\bullet$ ) pretreated with different concentrations of uranyl nitrate. The experiment was carried out in the sucrose medium. Optical density was measured after incubation for $30 \mathrm{~min}$. at room temperature and plotted as \% optical density of suspensions before the addition of detergents.

The non-ionic detergents Tween 80 and Triton had a much lower lytic activity than had the ionic detergents, and caused no lysis when the organisms were suspended in the sucrose medium. Some lysis occurred when Mycoplasma laidlawii was suspended in de-ionized water. None of the other Mycoplasma organisms nor the L-form of Streptobacillus miniliformis were lysed by non-ionic detergents, even when suspended in de-ionized water. 

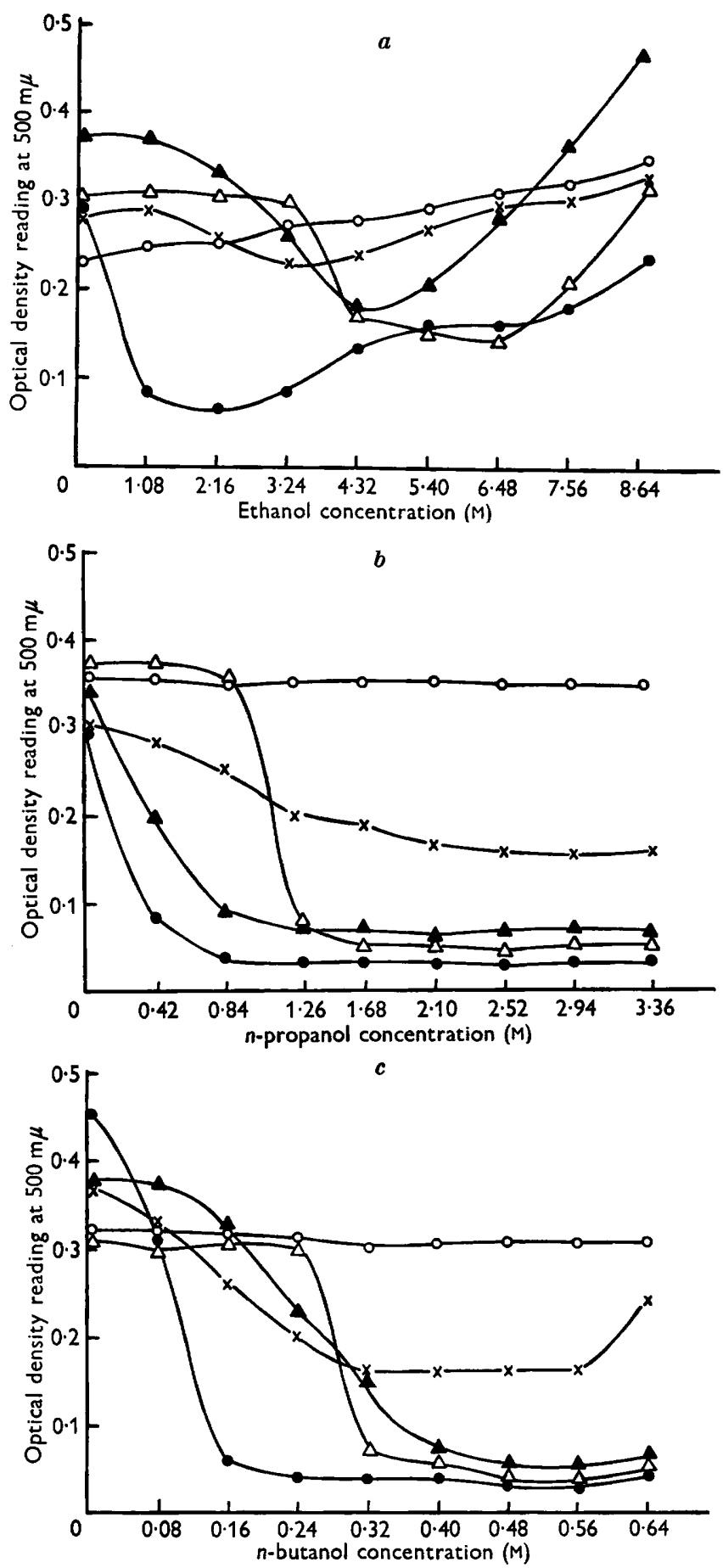

Fig. 7. Lysis by primary alcohols. (a) Ethanol; (b) $n$-propanol; (c) $n$-butanol. Mycoplasma laidlawii $(\triangle)$; Mycoplasma mycoides var. capri $(\Delta)$; L-form of Streptobacillus moniliformis (X); intact cells of Micrococcus lysodeikticus (O); protoplasts of $\boldsymbol{M}$. lysodeikticus ( $\bigcirc$ ). The experiment was carried out in the sucrose medium and optical density was measured after incubation for $\mathbf{3 0} \mathrm{min}$. at room temperature. 


\section{Lysis by alcohols}

The Mycoplasma protoplasts, like bacterial protoplasts, were very sensitive to lysis by primary alcohols (Fig. 7). On a molar basis the lytic effect of $n$-butanol was about four times greater than that of $n$-propanol and about ten times greater than that of ethanol. The increase in the optical density of the suspensions at high ethanol concentrations was apparently due to precipitation of the cellular components at these high alcohol concentrations. The L-form of Streptobacillus moniliformis was much more resistant to the lytic effects of alcohols than were the Mycoplasma organisms.

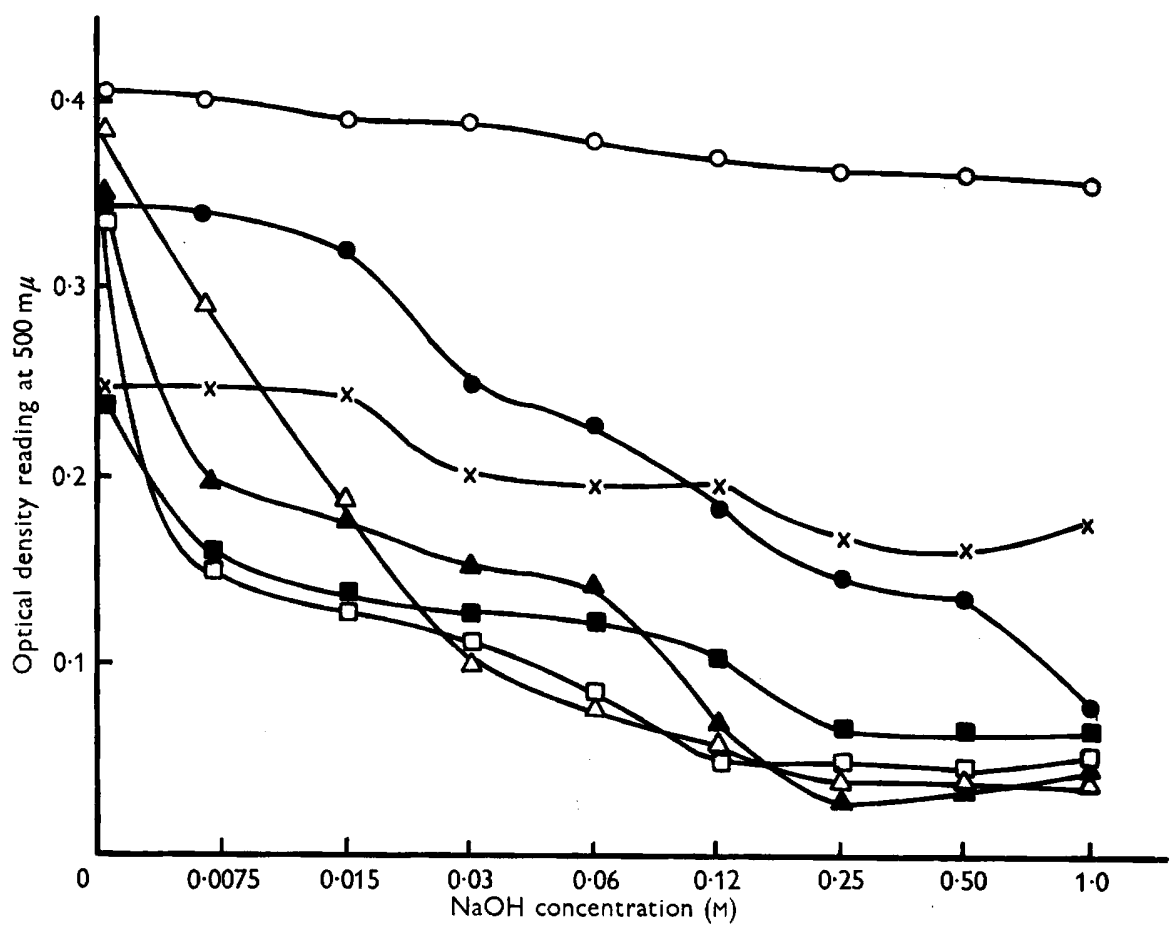

Fig. 8. Lysis by alkali. Mycoplasma laidlawii $(\Delta) ;$ Mycoplasma mycoides var. capri ( $\Delta$ ); Mycoplasma hominis ( $\mathrm{E})$; L-form of Streptobacillus moniliformis (X); spheroplasts of Escherichia coli $(\square)$; intact Micrococcus lysodeikticus (O); protoplasts of $\boldsymbol{M}$. lysodeikticus (๑). The experiment was carried out in the sucrose medium and the optical density measured after incubation for $\mathbf{3 0} \mathbf{~ m i n}$. at room temperature.

\section{Lysis by alkali}

All the organisms tested, except intact Micrococcus lysodeikticus, showed various degrees of sensitivity to lysis by $\mathrm{NaOH}$. Mycoplasma organisms and spheroplasts of Escherichia coli showed the highest sensitivity; bacterial protoplasts and Lforms were less sensitive to lysis by alkali (Fig. 8). Hydrochloric acid did not cause lysis of any of the test organisms within the range of concentrations 0.03-5.0 M. 


\section{Lysis by digitonin and saponin}

All the Mycoplasma strains tested showed a marked sensitivity to lysis by digitonin and saponin; all the other organisms tested were completely resistant. Human erythrocytes were more sensitive than Mycoplasma organisms to lysis by digitonin and saponin (Fig. 9). Washed digitonin-resistant organisms were not rendered sensitive to lysis by exposure to $0.01 \mathrm{mg}$. cholesterol $/ \mathrm{ml}$. in the sucrose medium for $3 \mathrm{hr}$. at $37^{\circ}$. Mycoplasma laidlarvii organisms grown in a cholesterolfree defined medium (Razin \& Cohen, 1962) were much more resistant to lysis by digitonin and saponin than were organisms grown in the cholesterol-containing Edward medium (Fig. 10).

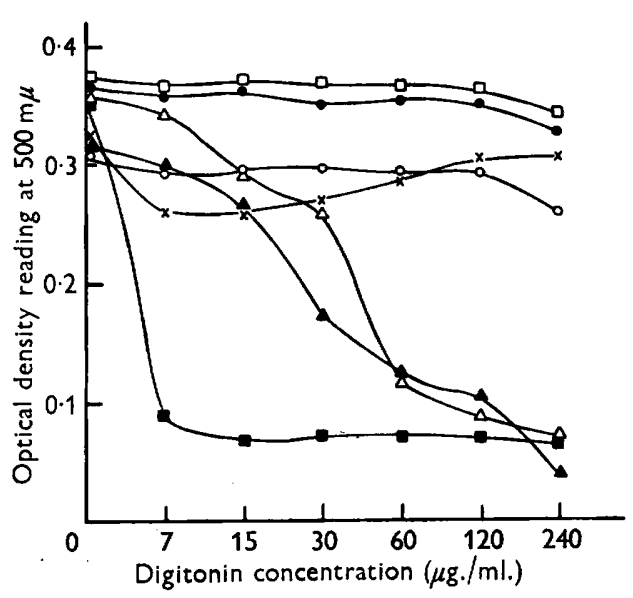

Fig. 9

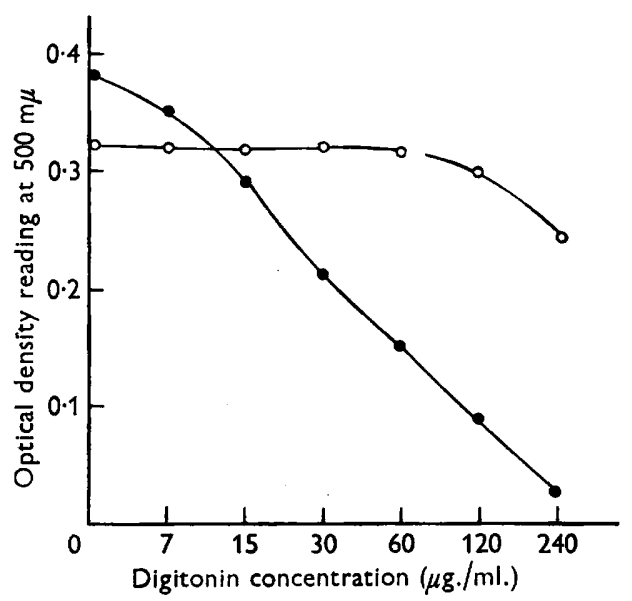

Fig. 10

Fig. 9. Lysis by digitonin. Mycoplasma laidlawii $(\triangle)$; Mycoplasma mycoides var. capri (A); L-form of Streptobacillus moniliformis $(X)$; spheroplasts of Escherichia coli $(\square)$; intact Micrococcus lysodeikticus (O); protoplasts of $M$. lysodeikticus (O); human erythrocytes $(\square)$. The experiment was carried out in the sucrose medium and the optical density measured after incubation for $30 \mathrm{~min}$. at room temperature.

Fig. 10. Lysis by digitonin of Mycoplasma laidlazwii grown in a cholesterol-free defined medium (Razin \& Cohen, 1962; O) or in the cholesterol-containing Edward medium (O). The experiment was carried out in de-ionized water and optical density measured after incubation for $30 \mathrm{~min}$. at room temperature.

\section{Lysis by enzymes}

Lysozyme. This enzyme had no lytic effect on Mycoplasma organisms or on the L-form of Streptobacillus moniliformis by any of the methods tested.

Lipase. Crude pancreatic lipase caused lysis of all the Mycoplasma strains examined. The lytic effect was greater in $0.067 \mathrm{M}-$ phosphate buffer $(\mathrm{pH} 7.0)$ than in 0.01 M-phosphate buffer (pH 8.0). Pancreatic lipase also caused lysis of bacterial protoplasts, spheroplasts and L-forms. Intact organisms of Micrococcus lysodeikticus and Escherichia coli were not lysed by this enzyme (Fig. 11).

Proteolytic enzymes. Trypsin had very little lytic effect on any fresh organism tested. A marked lytic effect was seen with the Mycoplasma organisms and spheroplasts of Escherichia coli when these were preheated at $70^{\circ}$ for $15 \mathrm{~min}$. The L-form 
of Streptobacillus moniliformis was insensitive to lysis by trypsin even when preheated. Of the other proteolytic enzymes tested, bromelin, like trypsin, acted only on heated organisms; papain had no lytic activity.

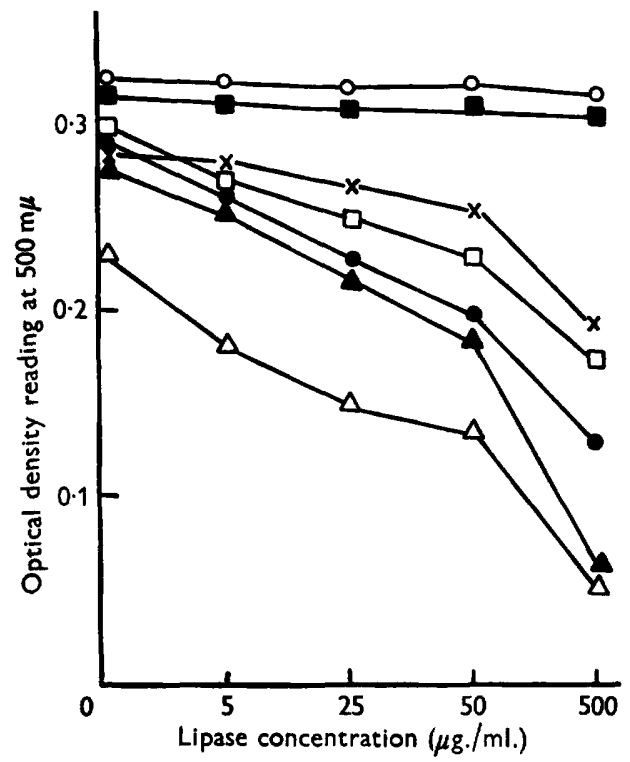

Fig. 11. Lysis by pancreatic lipase. Cells of Mycoplasma laidlawii $(\Delta)$, Mycoplasma mycoides var. capri (A); L-form of Streptobacillus moniliformis $(X)$; spheroplasts of Escherichia coli (口); protoplasts of Micrococcus lysodeikticus ( $($ ); intact cells of $M$.

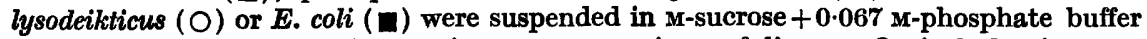
(pH 7.0) solution containing various concentrations of lipase. Optical density was measured at $37^{\circ}$ after incubation for $90 \mathrm{~min}$.

\section{DISCUSSION}

The relative resistance of Mycoplasma organisms to osmotic shock has been described by several authors (Smith \& Sasaki, 1958; Plackett, 1959; Butler \& Knight, 1960). Several hypotheses might be provided to explain the resistance of Mycoplasma to lysis by osmotic shock: $(a)$ The very small dimensions and spherical shape of most Mycoplasma organisms decrease the adverse effects of osmotic pressure changes (Mitchell \& Moyle, 1956b). Thus, the small elements of the L-form of Proteus vulgaris were much more resistant to osmotic shock than were the larger elements of this L-form (Thorsson \& Weibull, 1958). (b) The elasticity of the Mycoplasma envelope might permit considerable distension of the organism without its being ruptured. (c) The internal osmotic pressure of the Mycoplasma organisms might be low. There are marked differences between the internal osmotic pressures of different bacteria. Gram-positive cocci, such as Micrococcus lysodeikticus, have osmotic pressures of 20-30 atmospheres (Mitchell \& Moyle, 1956b) while Gram-negative rods have internal osmotic pressure of 4-8 atmospheres only (Gebicki \& James, 1960; Hugo \& Russell, 1960). Protoplasts of $M$. lysodeikticus therefore underwent almost complete lysis in $\mathbf{0 . 2 5}$ M-sucrose, while spheroplasts of Escherichia coli lysed to a similar degree only in $0.03 \mathrm{M}$-sucrose (Fig. 1). We have no direct way of 
measuring the internal osmotic pressure of Mycoplasma cells. However, indirect evidence for a low internal osmotic pressure was obtained while testing the sensitivity of Mycoplasma to lysis by alternate freezing and thawing. Mycoplasma organisms were lysed by this procedure when suspended in de-ionized water, but resisted lysis when sucrose or $\mathrm{NaCl}$ were added to the medium (Fig. 3). A concentration of $0 \cdot 12-0 \cdot 25 \mathrm{M}$-sucrose protected almost all Mycoplasma organisms against lysis by freezing and thawing. The protoplasts of $M$. lysodeikticus were lysed by alternate freezing and thawing, even when suspended in M-sucrose solution (Fig. 3). The protective effect of these solutes might be explained by the shrinkage of the plastic Mycoplasma cells by osmotic dehydration in hypertonic media (Postgate \& Hunter, 1961). The cell envelope of the shrunken cell is capable of resisting more efficiently the shearing forces of the ice crystals. If this explanation be correct, then $0.25 \mathrm{M}$-sucrose solution has to be regarded as hypertonic, and $0.12 \mathrm{M}$-sucrose as about isotonic, to the Mycoplasma organisms. The osmotic pressure of a $0.12 \mathrm{M}$ sucrose solution is about 3 atmospheres (Handbook of Chemistry \& Physics, 19541955). Hence, the internal osmotic pressure of Mycoplasma organisms seems to be remarkably low.

The marked resistance of the stable L-form of Streptobacillus moniliformis to lysis in hypotonic media might be explained along the same lines as the resistance of Mycoplasma organisms to osmotic shock. Medill-Brown, Hutchinson \& Cocklin (1960), on comparing the osmotic fragility of penicillin-induced spheroplasts and L-forms derived from Proteus mirabilis, found that the spheroplasts were much more sensitive to osmotic shock than were the L-forms. The agglutination of the Mycoplasma organisms by spermine and other polyamines indicates that the cell envelope of Mycoplasma has a net negative charge, like that of the bacterial protoplast membrane (Few, Gilby \& Seaman, 1960) and of bacterial cell walls (Razin \& Rozansky, 1959). The great sensitivity of Mycoplasma organisms to surface active substances is well known (Klieneberger-Nobel, 1962). Our studies have shown the close similarity between Mycoplasma organisms and bacterial protoplasts with respect to lysis by surface active agents. Mycoplasma organisms were lysed by about the same concentrations of ionic detergents as were bacterial protoplasts. Apparently the ionic detergents act on similar components present in the membranes of Mycoplasma organisms and of bacterial protoplasts, as indicated by the inhibition of lysis when the organisms were pre-treated with uranyl nitrate. Uranyl ions have a strong affinity for the phosphate groups of phospholipids present in the bacterial membrane (Gilby \& Few, 1960a). Since the cationic detergent cetyltrimethylammonium bromide (CTAB) combines with these acidic groups, its lytic action is inhibited more efficiently by uranyl ions than by the anionic detergent sodium lauryl sulphate (SLS), which combines mainly with the protein component of the membrane (Gilby \& Few, 1960a). The cationic detergent CTAB causes lysis of Mycoplasma organisms and bacterial protoplasts only within a narrow limit of concentrations. At concentrations higher than $5 \times 10^{-5} \mathrm{M}$ this detergent caused protein denaturation and 'fixation' of the organisms, as well as agglutination by neutralization of surface negative charge (Dawson, Lominski \& Stern, 1953).

The similar sensitivity of Mycoplasma organisms and bacterial protoplasts to lysis by primary alcohols and pancreatic lipase suggests the presence of a lipid component in the Mycoplasma cell envelope. Gilby \& Few (1960b) claimed that 
alcohols act on the lipid component of the protoplast membrane, causing lysis by disruption of membrane permeability. The marked lysis by alkali of all the organisms tested, except intact bacteria, is apparently due to the hydration and dispersion of cell proteins (Grula \& Hartsell, 1957). The mucopeptide polymer of the bacterial cell wall is alkali resistant and protects the intact bacterial cell from lysis. Digestion of the mucopeptide by lysozyme renders the bacteria sensitive to lysis by alkali (Grula \& Hartsell, 1957).

The most remarkable difference between Mycoplasma organisms and all the other organisms examined was the sensitivity of Mycoplasma to lysis by digitonin and saponin; lysis of Mycoplasma by digitonin was reported by Smith \& Rothblat (1960). This might be explained by the presence of cholesterol in the Mycoplasma cell envelope (Rothblat \& Smith, 1961; Razin \& Argaman, unpublished data). The much lower sensitivity of Mycoplasma laidlaziii to lysis by digitonin when grown in a cholesterol-free medium (Fig. 10) suggests that at least most of the cholesterol in this Mycoplasma species derives from the growth medium.

Our studies show that bacterial L-forms and spheroplasts are less sensitive to lysis than bacterial protoplasts and Mycoplasma organisms. The higher resistance of L-forms and spheroplasts to lysis might be attributed to the presence of a modified cell wall (Thorsson \& Weibull, 1958; Klieneberger-Nobel, 1960). The present findings and the morphological studies of ultrathin sections of Mycoplasma organisms (van Iterson \& Ruys, 1960) suggest that the Mycoplasma organisms are limited by a membrane of lipoprotein nature, very like that of the plasma membrane which encloses the bacterial protoplast. Chemical analysis of isolated Mycoplasma cell membranes also supports this assumption (Razin \& Argaman, to be published). The only difference so far found between the cell membrane of Mycoplasma and the plasma membrane of bacteria is the presence of cholesterol in the former.

Our thanks are due to Mrs E. Friedberg and Mr M. Wormser for their valuable technical assistance. This work was supported in part by a grant from the Joint Research Fund of the Hebrew University-Hadassah Medical School.

\section{REFERENCES}

Becker, M. E. \& Hartselt, S. E. (1954). Factors affecting bacteriolysis using lysozyme in dual enzyme systems. Arch. Biochem. Biophys. 53, 402.

BUtler, M. \& KNIGHT, B. C. J. G. (1960). The survival of washed suspensions of Mycoplasma. J. gen. Microbiol. 22, 470.

Dawson, I. M., Lominski, I. \& Stern, H. (1958). An electron-microscope study of the action of cetyl-trimethyl-ammonium bromide on Staphylococcus aureus. J. Path. Bact. 66, 513.

EDWARDS, G. A. \& Fogh, J. (1960). Fine structure of pleuropneumonia-like organisms in pure culture and in infected tissue culture cells. J. Bact. 79, 267.

Few, A. V., Gruby, A. R. \& Seaman, G. V. F. (1960). An electrophoretic study on structural components of Micrococcus lysodeikticus. Biochim. biophys. Acta, 38, 130.

GEBICKI, J. M. \& JAMES, A. M. (1960). The preparation and properties of spheroplasts of Aerobacter aerogenes. J. gen. Microbiol. 23, 9.

Gilby, A. R. \& FEw, A. V. (1959). Osmotic properties of protoplasts of Micrococcus lysodeikticus. J. gen. Microbiol. 20, 321.

Gruby, A. R. \& Few, A. V. (1960a). Lysis of protoplasts of Micrococcus lysodeikticus by ionic detergents. J. gen. Microbiol. 23, 19. 
Gilby, A. R. \& FEw, A. V. (1960b). Lysis of protoplasts of Micrococcus lysodeikticus by alcohols. J. gen. Microbiol. 23, 27.

Gilby, A. R., FEw, A. V. \& McQunLlen, K. (1958). The chemical composition of the protoplast membrane of Micrococcus lysodeikticus. Biochim. biophys. Acta, 29, 21.

GrULA, E. A. \& Hartsell, S. E. (1957). Lysozyme in the bacteriolysis of Gram-negative bacteria. II. Factors influencing clearing during the Nakamura treatment. Canad. $J$. Microbiol. 3, 23.

Handbook of Chemistry and Physics (1954-1955), 36th ed. Ed. C. D. Hodgman. Cleveland, Ohio, U.S.A.: Chemical Rubber Publishing Co.

Hugo, W. B. \& Russell, A. D. (1960). Quantitative aspects of penicillin action on Escherichia coli in hypertonic medium. J. Bact. 80, 436.

ImaEda, T. \& Convit, J. (1962). Electron microscope study of Mycobacterium leprae and its environment in a vesicular leprous lesion. J. Bact. 83, 43.

KANDLER, O. \& ZEHENDER, C. (1957). Utber das Verkommen von $\alpha, \epsilon$-Diaminopimelinsäure bei verschiedenen L-Phasentypen von Proteus vulgaris und bei den pleuropneumonieähnlichen Organismen. Z. Naturf. $12 b, 725$.

KuIENEBerger-Nobet, E. (1960). L-forms of bacteria. In The Bacteria, A Treatise on Structure and Function, vol. 1, p. 361. Ed. I. C. Gunsalus \& R. Y. Stanier. New York: Academic Press Inc.

KLIENEBerger-Nobed, E. (1962). Pleuropneumonia-like organisms (PPLO) Mycoplasmataceae. London: Academic Press.

KoHN, A. (1960). Lysis of frozen and thawed cells of Escherichia coli by lysozyme, and their conversion into spheroplasts. J. Bact. 79, 697 .

Lederberg, J. (1956). Bacterial protoplasts induced by penicillin. Proc. nat. Acad. Sci., Wash. 42, 574.

Medill-Brown, M., Hutchinson, W. G. \& Cocklin, E. (1960). The L-forms of Proteus mirabilis. Ann. N.Y. Acad. Sci. 79, 874.

Mrtcheld, P. \& Moyle, J. (1956a). Liberation and osmotic properties of the protoplasts of Micrococcus lysodeikticus and Sarcina lutea. J. gen. Microbiol. 15, 512.

Mrtcheld, P. \& Moyle, J. (1956b). Osmotic function and structure in bacteria, in Bacterial Anatomy. Symp. Soc. gen. Microbiol. 6, 150.

Plackett, P. (1959). On the probable absence of 'mucocomplex' from Mycoplasma mycoides. Biochim. biophys. Acta, 35, 260.

Postgate, J. R. \& Hunter, J. R. (1961). On the survival of frozen bacteria. J. gen. Microbiol. 26, 367.

Razin, S. \& Argaman, M. (1961). Properties of the Mycoplasma (PPLO) cell envelope. Bull. Res. Coun. Israel, $9 \mathrm{E}, 121$.

RAzin, S. \& CoHEN, A. (1962). Nutritional requirements and metabolism of Mycoplasma laidlawii. J. gen. Microbiol. 30, 141.

Razin, S. \& Oliver, O. (1961). Morphogenesis of Mycoplasma and bacterial L-form colonies. J. gen. Microbiol. 24, 225.

Razin, S. \& Rozansky, R. (1959). Mechanism of the antibacterial action of spermine. Arch. Biochem. Biophys. 81, 36.

REPASKe, R. (1956). Lysis of Gram-negative bacteria by lysozyme. Biochem. biophys. Acta, 22, 189.

Robertson, J. D. (1959). The ultrastructure of cell membranes and their derivatives. Biochem. Soc. Symp. 16, 3.

Rodwell, A. W. \& Aввот, A. (1961). The function of glycerol, cholesterol and long-chain fatty acids in the nutrition of Mycoplasma mycoides. J. gen. Microbiol. 25, 201.

Rothblat, G. H. \& Smrth, P. F. (1961). Nonsaponifiable lipids of representative pleuropneumonia-like organisms. J. Bact. 82, 479.

RuYs, A. C. \& Van Iterson, W. (1961). Some characteristics of pathogenic avian PPLO. Antonie van Leeurvenhoek J. Microbiol. Serol. $27,129$.

ShARP, J. T. (1960). The cell wall of bacterial L-forms and pleuropneumonia-like organisms. Ann. N.Y. Acad. Sci. 79, 344. 
Smith, P. F. \& Rothblat, G. H. (1960). Incorporation of cholesterol by pleuropneumonialike organisms. $J$. Bact. $80,842$.

Smrth, P..F. \& SASaki, S. (1958). Stability of pleuropneumonia-like organisms to some physical factors. Appl. Microbiol. 6, 184.

Smolelis, A. N. \& Hartseli, S. E. (1949). The determination of lysozyme. J. Bact. 58, 731.

TABOR, H., TABor, C. W. \& Rosenthat, S. M. (1961). The biochemistry of the polyamines: spermidine and spermine. Ann. Rev. Biochem. 30, 579.

Thonsson, K. G. \& Werbuld, C. (1958). Studies on the structure of bacterial L-forms protoplasts and protoplast-like bodies. J. Ultrastr. Res. $1,412$.

van ItErson, W. (1961). Some features of a remarkable organelle in Bacillus subtilis. J. biophys. biochem. Cytol. 9, 183.

van Iterson, W. \& RUYS, A. C. (1960). The fine structure of the Mycoplasmataceae (micro-organisms of the pleuropneumonia group = PPLO). 1. Mycoplasma hominis, $M$. fermentans and M. salivarium. J. Ultrastr. Res. 3, 282.

WexBuld, C. \& Bergström, L. (1958). The chemical nature of the cytoplasmic membrane and cell wall of Bacillus megaterium, strain M. Biochim. biophys. Acta, 30, 340. 


\section{CORRIGENDA}

In Bojalil, L. F., Cerbon, J. \& Trujillo, A. (1962).

J. Gen. Microbiol. 28, 333-346.

Insert on page $\mathbf{3 3 5}$.

Adansonian classification

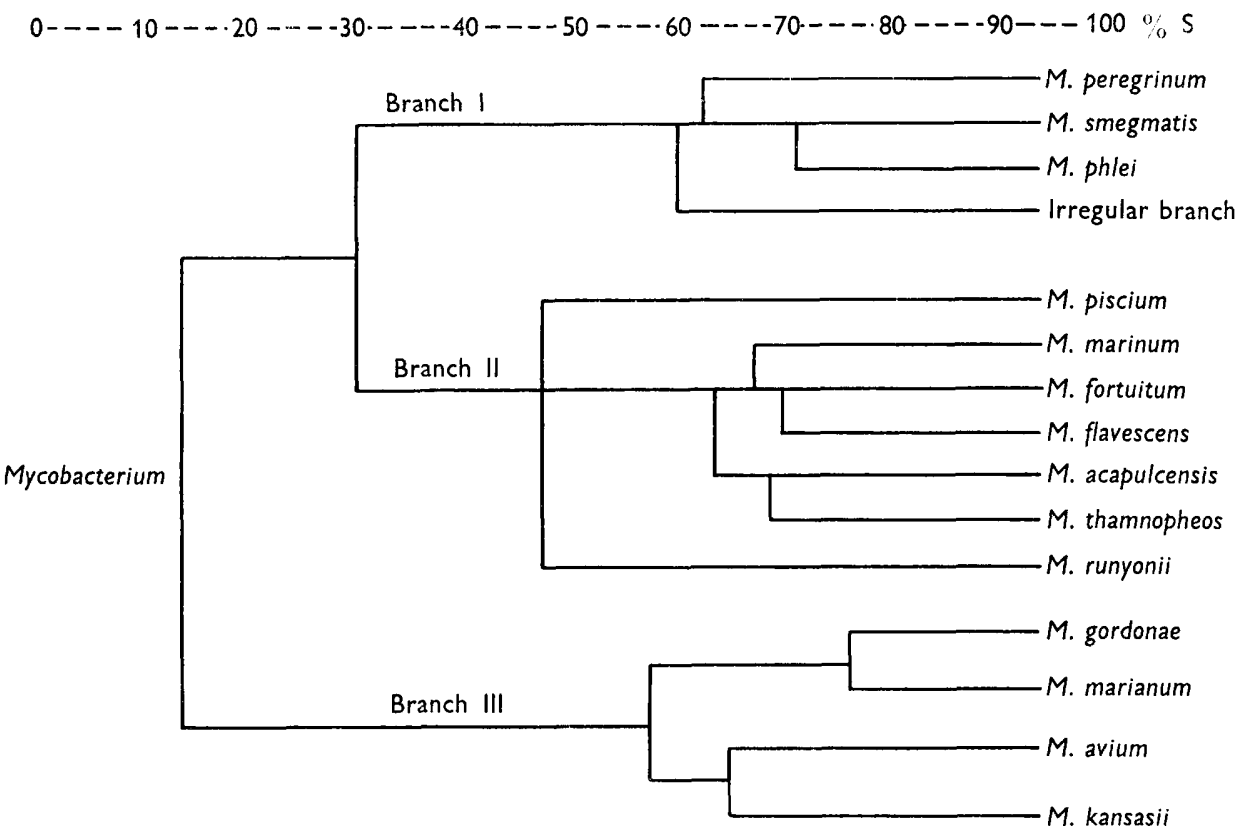

Fig. 2. Taxonomic tree of the mycobacteria. Branch I, high metabolic capacity; Branch II, intermediate metabolic activity; Branch III, low metabolic activity.

On page 342, for Fig. 2 read Fig. 3. 